\title{
Hadis Maudhu dan Akibatnya
}

Oleh: Rabiatul Aslamiah

\section{Abstrak}

Segala sesuatu yang disandarkan kepada Rasulullah Saw menjadi sumber ajaran,panutan dan nilai yang sangat berharga bagi ummat Islam. Dari penelitian yang dilakukan para ulama hadis,ternyata ada hadis-hadis yang tidak layak untuk dijadikan sumber ajaran karena keberadaannya tidak memenubi kriteria yang ditetapkan, hadis itulah yang disebat maudhu (palsu). Hadis-hadis semacam itu dapat menimbulkan dampak negatif diantaranya: Menimbulkan dan mempertajam perpecahan dikalangan ummat Islam, mencemarkan pribadi Nabi saw, mengaburkan pemahaman terhadap Islam serta melemabkan jiwa dan semangat keislaman.

Kata Kunci: Rasulullah saw, Hadis maudhu, akibat.

\section{A. Pendahuluan}

Hadits sebagai sumber hukum Islam setelah Al Qur'an telah disepakati oleh ulama tokohtokoh ummat Islam. Setiap gerak dan aktivitas ummat, harus dilakukan berdasarkan petunjuk yang ada dalam al Qu'an dan dan hadits. Begitu pula jika ada permasalahan yang yang muncul di tengah tengah masyarakat, tentu haruslah diselesaikan dan dicarikan jalan keluarnya. Cara penyelesaian dan jalan keluar yang terbaik adalah dengan berpedoman kepada Al Qur'an dan Hadits.

Namun sangat disayangkan keberadaan hadis yang benar-benar berasal dari Rasulullah saw, dinodai oleh munculnya hadis-hadis maudhu (palsu) yang sengaja dibuat-buat oleh orangorang tertentu dengan tujuan dan motif yang beragam, dan disebarkan ditengah-tengah masyarakat oleh sebagian orang dengan tujuan yang beragam pula.

Meyakini dan mengamalkan hadis maudhu merupakan kekeliruan yang besar, karena meskipun ada hadis maudlu yang isinya baik, tetapi kebanyakan hadis palsu itu bertentangan dengan jiwa dan semangat Islam, lagi pula pembuatan hadis maudlu merupakan perbuatan dusta kepada Nabi Muhammad saw.

\section{Pengertian Hadits Maudhu'}

Apabila dilihat dari segi bahasa, kata maudhu' merupakan bentuk isim maful dari kata - وضع Kata وضع Memiliki beberapa makna, antara lain:

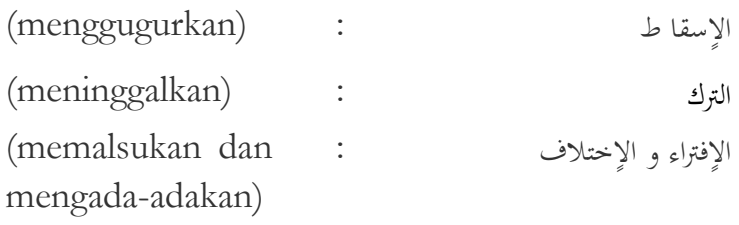

Adapun pengertian maudhu' menurut istilah ulama hadits yaitu:

هو ما نسب إلى الرسول صلئٌ الله عليه و سلُم واختلاقا و كذبا هما لم يقله

Artimya: "Sesuatu yang dinisbabkan kepada Rasulullah saw dengan cara mengada-ada dan dusta, yaitu yang tidak pernah beliau sabdakan, beliau kerjakan maupun beliau taqrirkan". ( Ajaj Al-Khatib, Ushul al Hadist 1981:415)

Para ahli hadis mendefinisikan bahwa Hadis Maudhu adalah: Hadis yang diciptakan dan dibuat-buat oleh orang-orang pendusta dan kemudian dikatakan bahwa itu hadis Rasulullah saw. (Subhi Shalih, Ulumul hadts wa Musthalahubu, :263)

Dari pengertian di atas dapat kita simpulkan bahwa Hadist mandhu' adalah segala sesuatu (riwayat) yang disandarkan pada Nabi Muhammad saw, baik perbuatan, perkataan, maupun taqrir secara di buat-buat atau disengaja dan sifatnya mengada-ada atau berbohong. Tegasnya hadis maudhu adalanh hadis yang diada-ada atau dibuat-buat (Ajaj al Khatib, Ushulul Hadits : 415). 
Hadis semacam ini tentu saja tidak benar dan tidak dapat diterima tanpa terkecuali, sebab ini sesungguhnya bukan hadis, tindakan demikian adalah merupakan pendustaan terhadap Nabi Muhammad saw. yang pelakunya diancam dengan neraka. dan hadis ini haram untuk disampaikan pada masyarakat umum kecuali hanya sebatas memberikan penjelasan dan contoh bahwa hadist tersebut adalah maudhu' (palsu).

\section{Sejarah Munculnya Hadis maudhu'}

Masuknya secara massal penganut agama lain ke dalam Islam, yang merupakan bukti keberhasilan dakwah Islamiyah ke seluruh dunia, secara tidak langsung menjadi factor yang menyebabkan munculnya hadist-hadist palsu. Tidak bisa diingkari bahwa masuknya mereka ke Islam, di samping ada yang benar-benar murni tertarik dan percaya kepada ajaran Islam yang dibawa oleh Nabi Muhammad, tetapi ada juga segolongan mereka yang menganut agama Islam hanya karena terpaksa tunduk pada kekuasaan Islam pada waktu itu. Golongan ini kita kenal dengan kaum munafik dan Zindiq.

Terjadinya pertikaian politik yang terjadi pada akhir masa pemerintahan khalifah Utsman bin Affan dan Khalifah Ali bin Abi Thalib merupakan awal adanya benih-benih fitnah, yang memicu munculnya pemalsuan hadis,tetapi pada masa ini belum begitu meluas karena masih banyak sahabat ulama yang masih hidup dan mengetahui dengan penuh yakin akan kepalsuan suatu hadist. Para sahabat ini mengetahui bahaya dari hadist maudhu'karena ada ancaman yang keras dikeluarkan oleh Nabi SAW terhadap orang yang memalsukan hadist, Namun pada masa sesudahnya, yaitu pada akhir pemerintahan Khalifah Bani Umayyah pemalsuaan hadis mulai marak, baik yang dibuat oleh ummat Islam sendiri, maupunyang dibuat oleh orang diluar Islam. Menurut penyaksian Hammad bin Zayyad terdapat 14.000 hadis maudhu. Abdul Karim al Auja mengaku telah membuat 4.000 Hadis maudhu.

Terpecahnya ummat Islam menjadi beberapa golongan politik dam keagamaan menjadi pemicu munculnya hadis maudhu. Masing-masing pengikut kelompok ada yang berusaha memperkuat kelompoknya dengan mengutip dalil dalil dari Al Qur'an dan hadis, menafsirkan/men' tawilkan Al Qur'an dan hadis menyimpang dari arti sebenarnya, sesuak denagan keinginan mereka. Jika mereka tidak dapat menemukan yang demikian itu maka membuat hadis dengan cara mengada-ada atau berbohong atas diri Rasulullah saw. Maka muncullah hadis-hadis tentang keutamaan para khalifah (secara berlebihan) dan para pemimpin golongan dan mazhab (Ajaj al Khatib : 416)

Menurut Subhi Shalih, hadis maudhu mulai muncul sejak tahun $41 \mathrm{H}$, yaitu ketika terjadi perpecahan antara Ali bin Abi Thalib yang didukung oleh penduduk Hijaz dan Irak dengan Muawiyah bin Abi Sufyan yang didukung oleh penduduk Syria dan Mesir, Ummat Islam terbagi kepada beberapa firqah: Syiah, Khawarij dan Jumbur. Karena itu menurut Subhi Shaleh, bahwa tmbulnya Firqah-firqah dan mazhab merupakan sebab yang paling penting bagi timbulnya usaha mengada -ada habar dan hadis.(Subhi Shalih : 266-267).

\section{Faktor-faktor Penyebab Munculnya Hadist Maudhu'}

Bertitik tolak dari hadis-hadis maudhu yang tersebar, nampaknya motivasi dan tujuan pembuatan hadis maudhu bervariasi, diantaranya :

\section{a. Faktor Politik}

Pertentangan di antara umat Islam timbul setelah terjadinya pembunuhan terhadap khalifah Utsman bin Affan oleh para pemberontak dan kekhalifahan digantikan oleh Ali bin Abi Thalib menyebabkan Umat Islam pada masa itu terpecah-belah menjadi beberapa golongan, seperti golongan yang ingin menuntut bela terhadap kematian khalifah Utsman dan golongan yang mendukung kekhalifahan Ali (Syi'ah). Setelah perang Siffin, muncul pula beberapa golongan lainnya, seperti Khawarij dan golongan pendukung Muawiyyah, masingmasing mereka mengklaim bahwa kelompoknya yang paling benar sesuai dengan ijtihad mereka, masing- masing ingin mempertahankan 
kelompoknya, dan mencari simpati massa yang paling besar dengan cara mengambil dalil AlQur'an dan Hadist. Jika tidak ada dalil yang mendukung kelompoknya, mereka mencoba mentakwikan dan memberikan interpretasi (penafsiran) yang terkadang tidak layak. Sehingga mereka membuat suatu hadist palsu seperti Hadist - Hadist tentang keutamaan para khalifah, pimpinan kelompok, dan aliranaliran dalam agama. Yang pertama dan yang paling banyak membuat hadist maudbu' adalah dari golongan Syi'ab dan Rafidhah. Kelompok syi'ah membuat hadis tentang wasiat nabi bahwa Ali adalah orang yang paling berhak menjadi khalifah setelah beliau dan mereka menjatuhkan orang-orang yang dianggap lawan-lawan politiknya, yaitu Abu Bakar, Umar, dan lain-lain. Diantara hadis maudlu tersebut:

$$
\text { وصيّيّ و موقع سرّي و خليفتي في أهلي خير من أخلف بعدي عليّ }
$$

Artinya: "Yang menerima wasiatku, dan yang menjadi tempat rahasiaku dan penggantiku dari keluargaku adalah Ali.

Di pihak Mu'awiyah ada pula yang membuat hadis maudhu sebagai berikut:

$$
\text { الامناء عند اللة ثلا ثه انا وجبريل ومعا ويه }
$$

Artinya: "Orangyang dapat dipercaya disisi Allah ada tiga yaitu: Aku, Jibril dan Mu'awiyab".

\section{b. Faktor Kebencian dan permusuhan.}

Keberhasilan dakwah Islam myebabkan masuknya pemeluk agama lain kedalam Islam, namun ada diantara mereka ada yang masih menyimpan dendam dan sakit hati melihat kemajuan Islam. Mereka inilah yang kemudian membuat hadis-hadis maudhu. Golongan ini terdiri dari golongan Zindiq, Yahudi, Majusi, dan Nasrani yang senantiasa menyimpan dendam dan benci terhadap agama Islam. Mereka tidak mampu untuk melawan kekuatan Islam secara terbuka maka mereka mengambil jalan yang buruk ini, yaitu menciptakan sejumlah hadist maudbu' dengan tujuan merusak ajaran Islam dan menghilangkan kemurnian dan ketinggiannya dalam pandangan ahli fikir dan ahli ilmu. Diantara hadis yang dibuat kelompok ini yaitu:

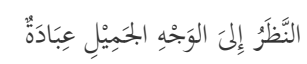

Artinya: "Melihat (memandang) kepada muka yang indah, adalah ibadat".

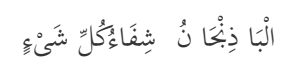

Artinya: "Buab terong itu, penawar bagi segala penyakit".

Ada yang berpendapat bahwa faktor ini merupakan faktor awal munculnya hadist maudhu'. Hal ini berdasarkan peristiwa Abdullah bin Saba' yang mencoba memecah-belah umat Islam dengan mengaku kecintaannya kepada Ahli Bait. Sejarah mencatat bukti bahwa ia adalah seorang Yahudi yang berpura-pura memeluk agama Islam. Oleh sebab itu, ia berani menciptakan hadist maudhu'pada saat masih banyak sahabat ulama masih hidup.

Tokoh-tokoh terkenal yang membuat hadist maudhu' dari kalangan orang zindiq ini, adalah:

1) Abdul Karim bin Abi Al-Auja, telah membuat sekitar 4000 hadist maudhu'tentang hukum halalharam, ia membuat hadis untuk menghalalkan yang haram dan mengharamkan yang halal. Akhirnya, ia dihukum mati olen Muhammad bin Sulaiman, Walikota Bashrah.

2) Muhammad bin Sa'id Al-Mashlub, yang dihukum bunuh oleh Abu Ja'far AlMashur.

3) Bayan bin Sam'an Al-Mahdy, yang akhirnya dihukum mati oleh Khalid bin Abdillah.

\section{c. Faktor Kebodohan.}

Ada golongan dari ummat Islam yang suka beramal ibadah namun kurang memahami agama, mereka membuat at hadist-hadis maudlu (palsu) dengan tujuan menarik orang untuk berbuat lebih baik dengan cara membuat hadis yang berisi dorongan-dorongan untuk meningkatkan amal dengan menyebutkan kelebihan dan keutamaan dari amalan tertentu tanpa dasar yang benar melalui hadist targhib yang mereka buat sendiri. Biasanya hadis palsu semacam ini menjanjikan pahala yang sangat besar kepada perbuatan kecil. Mereka juga membuat hadis maudhu (palsu) yang berisi 
dorongan untuk meninggalkan perbuatan yang dipandangnya tidak baik dengan cara membuat hadis maudhu yang memberikan ancaman besar terhadap perbutan salah yang sepele. Diantaranya hadis palsu itu :

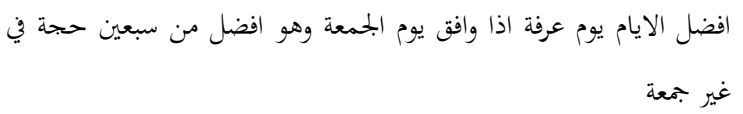

Artinya: "Sentama-utama hari adalah hari wnkuf di Arafah, apabila (bari wukuf di arafah) bertepatan dengan hari jum'at, maka hari itu lebih utama daripada tujub pulub haji yang tidak bertepatan dengan hari jum'at."

Menurut al Qur'an yang dimaksud haji akbar adalah ibadah haji itu sendiri ( Al Qur'an Surah Attaubah : 3) dengan pengertian bahwa ibadah umrah disebut dengan haji kecil.

Hadis maudhu itu dibuat oleh muballig /guru agama yang ingin memberi nilai lebih kepada ibadah haji yang wukufnya bertepatan dengan hari jum'at.

\section{d. Fanatisme yang keliru}

Sikap sebagian penguasa Bani Umayah yang cenderung fanatisme dan rasialis, telah ikut mendorong kalangan Mawali untuk membuat hadits-hadits palsu sebagai upaya untuk mempersamakan mereka dengan orang-orang Arab.Misalnya:

$$
\text { ابغض الكلام إلى الله الفارسية.... وكلام أهل الجنة العربية }
$$

Artinya: "Percakapan yang paling dimurkai Allah adalah bahasa Persia dan bahasa penghuni surga adalah bahasa Arab"

Selain itu,Fanatisme Madzhab dan Teologi juga menjadi factor munculnya hadis palsu, seperti yang dilakukan oleh para pengikut Madzhab Fiqh dan Teologi, diantaraya:

$$
\text { من رفع يده في الركوع فلا صلاة له }
$$

Artinya: "Barang siapa yang mengangkat tangannya ketika ruku', maka tiadalah shalat baginya"

Hadis ini diduga dibuat oleh pengikut mazhab yang tidak mengangkat tangan ketika ruku'.

\section{e. Faktor Popularitas dan Ekonomi}

Sebagian tukang cerita yang ingin agar apa yang disampaikan nya menarik perhatian orang, dia berusaha mengumpulkan orang dengan cara membuat hadits-hadits palsu yang membuat masyarakat suka dan tertarik kepada mreka, menggerakkan keinginan, juga memberikan harapan bagi mereka.Misalnya:

من قال لآله إلّا الله, خلق الله من كلّ كلمة طائرا, منقاره من ذهب وريشه من مرجان

Artinya: "Barang siapa membaca la ilaha illallah, niscaya Allab menjadikan dari tiap-tiap kalimatnya seekor burung, parubnya dari emas dan buabnya dari marjan".

Demikian juga para pegawai dan tokoh masyarakat yang ingin mencari muka (menjilat) kepada penguasa membuat hadsi-hadis mandbu untuk tujuan supaya lebih dekat dengan penguasa agar mendapatkan fasilitas tertentu atau popularitas saja. Misalnya Ghiyadh Ibn Ibrahim ketika datang kepada khalifah Al Mahdi yang pada saat itu sedang mengadu burung merpati, Ghiyadh memalsukan hadis berikut:

$$
\text { لا سبق إلّا في نصيل أو حفّ أو حافر اوجناح }
$$

Artinya: "Tidak ada perlombaan kecuali pada panah, unta kuda dan burung"

Kata "Janah" adalah tambahan yang dibuat oleh Ghiyadh untuk menarik simpati dari Khalifah al Mahdi.

Para pedagang barang-barang tertentu juga membuat hadis- hadis palsu tentang keutamaan barang dagangannya misalnya.

$$
\text { الديك الابيض حبيبي وحبيب حبيبي جبريل }
$$

\section{"Artinya: Ayam putih adalah kekasibku dan kekasih} oleh kekasibku Jibril"

Hasbi Assiddiqy menjelaskan bahwa golongan yang membuat hadis maudhu itu ada sembilan golongan yaitu:

1) Zanadiqah (orang orang zindiq)

2) Penganut-penganut bid'ah.

3) Orang-orang dipengaruhi fanatik kepartaian

4) Orang-orang yang ta'ashshub kepada kebangsaan, kenegerian dan kkeimanan.

5) Orang-orang yang dipengaruhi ta'ashshub mazhab.

6) Para Qushshas ( ahli riwayat dongeng).

7) Para ahli Tasawuf zuhhad yang keliru. 
8) Orang-orang yang mencarai pengahrgaan pembesar negeri.

9) Orang - orang yang ingin memegahkan dirinya dengandapat meriwayatkan hadis yang diperoleh orang lain. ( Hasbi Ashshiqqiqy, Sejarah dan Pengantar Ilmu Hadis: 255)

\section{Ciri-ciri Hadis Maudhu}

Indikasi ke-maudhu' an hadist adakalanya berkaitan dengan rawi/ sanad dan mungkin pula berkaitan dengan matan.

a. Ciri yang berkaitan dengan rawi / sanad:

1) Periwayatnya dikenal sebagai pendusta, dan tidak ada jalur lain yang periwayatnya tsiqoh meriwayatkan hadist itu. Misalnya, Ketika saad ibn Dharif mendapati anaknya pulang sekolah sedang menangis dan mengatakan bahwa dia dipukul gurunya, maka Saad ibn Dharif berkata : Bahwa Nabi saw bersabda:

معلموا صبيانكم شراركم اقلهم رحمة لليتم واغلظهم على المسكين Artinya: "Guru anak kecil itu adalah yang paling jahat diantara kamu, merekeka paling sedikit kasih sayangnya kepada anak yatim dan paling kasar terhadap orang miskin."

Al Hafdz Ibnu Hibban mengatakan bakwa Saad ibn Dharif adalah seorang pendusta/ pemalsu hadits. ( Mustahafa Zahri, Kunci memahami Musthalahul Hadits : 101)

2) Periwayatnya mengakui sendiri membuat hadist tersebut. Maisarah ibn Abdirrabih al Farisi mengaku bahwa dia telah membuat hadis maudhu tentang keutamaan $\mathrm{Al}$ qur'an.., dan ia juga mengaku membuat hadis maudhu tentang keutamman Ali ibn Abi Tahalib sebanyak 70 buah hadis. (Musthafa Zahri, : 100).

3) Ditemukan indikasi yang semakna dengan pengakuan orang yang memalsukan hadist, seperti seorang periwayat yang mengaku meriwayatkan hadist dari seorang guru yang tidak pernah bertemu dengannya. Karena menurut kenyataan sejarah guru tersebut dinyatakannya wafat sebelum ia sendiri lahir. Misanlnya, Ma'mun ibn Ahmad al Harawi mengaku mendengar hadis dari Hisyam ibn Hammar. Al hafiz ibn Hibban menanyakan kapan Ma'mun datang ke Syam? Ma'mun menjawab: tahun 250. Maka ibnu Hibban mengatakan banwa Hisyam ibn Ammar wafat tahun 254. Ma'mun menjawab bahwa itu Hisyam ibn Ammar yang lain.( Musthafa Zahri, : 100).

\section{b. Ciri-ciri yang berkaitan dengan Matan}

Kepalsuan suatu hadis dapat dilihat juga pada matan, berikut ciri-cirinya:

1) Kerancuan redaksi atau Kerusakan maknanya.

2) Berkaitan dengan kerusakan ma.na tersebut, Ibnu Jauzi berkata: Saya sungguh malu dengan adanya pemalsuan hadis. Dari sejumlah hadis palsu, ada yang mengatakan: "Siapa yang salat, ia mendapatkan 70 buah gedung, pada setiap gedung ada 70.000 kamar, pada setiap kamar ada 70000 tempat tidur, pada setiap tempat tidur ada 70000 bidadari. Perkataaan ini adalah rekayasa yang tak terpuji. (Nuruddin : 323)

3) Setelah diadakan penelitian terhadap suatu hadis ternyata menurut ahli hadis tidak terdapat dalam hafalan para rawi dan tidak terdapat dalam kitab-kitab hadis.

Misalnya perkataan yang berbunyi:

الله اخذ الميثاق علي كل مؤمن ان يبغض على منا فق وعلي كل منا فق ان ان ييغض كل مؤمن

Artinya: "Sesungguhnya Allah telah mengambil Janji kepada setiap orang mukmin untuk membenci kepada setiap munafik, dan kepada setiap munafik untuk membenci kepada setiap mukmin"

4) Perkataan diatas tidak diketahui sumbernya. 
Hadisnya menyalahi ketentuan-ketentuan yang telah ditetapkan, seperti ketentuan akal, tidak dapat ditakwil, ditolak oleh perasaan, kejadian empiris dan fakta sejarah.

Misalnya perkataan yang berbunyi:

$$
\text { اذا عطشس الرجل عند الحديث فهودليل صدقه }
$$

Artinya "Tika seseorang bersin ketika membacakan suatu hadis, maka itu menandakan bahwa pembicaraanya benar"

5) Hadisnya bertentangan dengn petunjuk Al-Quran yang pasti. Misalnya:

$$
\text { ولد الزنا لايدخل الجنة الي سيعة ابناء }
$$

Artinya: "Anak zina tidak masuk syurga hingga tujub turunan"

Hadis tersebut bertentangan dengan ayat al Qur'an :

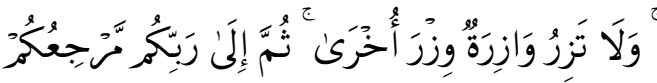

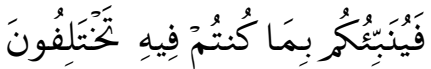

Artinya: "dan seorang yang berdosa tidak akan memikul dosa orang lain[526]. kemudian kepada Tuhanmulah kamu kembali, dan akan diberitakan-Nya kepadamu apa yang kamu perselisibkan."(QS Al An'am :164)

Musthafa Assiba’i memuat tujuh macam ciri Hadis palsu yaitu:

1) Susunan Gramatikanya sangat jelek.

2) Maknanya sangat bertentangan dengan akal sehat.

3) Menyalahi $\mathrm{Al}$ qur'an yang telah jelas maksudnya.

4) Menyalahi kebenaran sejarah yang telah terkenal di zaman Nabi saw.

5) Bersesuaian dengan pendapat orang yang meriwayatkannya, sedang orang tersebut terkenal sangat fanatic terhadap mazhabnya.

6) Mengandung suatu perkara yang seharusnya perkara tersebut diberitakan oleh orang banyak, tetapi ternyata diberitakan oleh seorang saja.

7) Mengandung berita tentang perberian pahala yang besat untuk perbuatan kecil, atau ancaman siksa yang berat terhadap suatu perbuatan yang tidak berarti Syuhudi Ismail : 178).

Menurut Hasbi Ashshddiqy, ciri Hadis palsu apabila:

1) Maknanya berlawanan dngan hal-hal yang mudah dipahami.

2) Berlawanan dengan ketentuan umum dan akhlak atau menyalahi kenyataan.

3) Berlawanan denga ilmu kedokteran.

4) Menyalahi peraturan- peaturan akal terhadap Allah.

5) Menyalahi ketentuan Allah dalam menjadikan alam.

6) Mengandung dongengan- dongengan yang tidak dibenarkan akal.

7) Menyalahi keterangan Al Qur'an yang terang tegas.

8) Menyalahi kaedah umum.

9) Menyalahi hakikat sejarah yang telah terkenal dimasa Nabi saw.

10) Sesuai dengan mazhab yang dianut perawi, sedang perawi itu orang sangat fanatic mazhabnya.

11) Menerangkan urusan yang seharusnya kalau ada dinukilkan oleh orang banyak.

12) Menerangkan pahala yang sangat besar terhadap suatu perbuatan kecil atau siksaan yang amat besar terhadap suatu amal yang tak berarti: (Hasbi Ashshiddiqy, pokok-pokok ilmu Dirayah Hadis: .369-374)

Mustahafa Zahri dalam buku "Kunci Memahami Musthalah Hadits" memberikan ciri hadis maudhu berikut:

1) Berlawanan dengan pendapat akal sehat. Misalnya:

$$
\text { من اتخذ ديكا ابيض لم يقربه شيطان }
$$

Artinya: "Siapa yang memelibara ayam putib niscaya tidak disekati syaithan"

2) Berlawanan dengan al Qur'an, contohnya:

Artinya: "Umur Dunia itu 7000 tahun, dan sekarang sudah pada ribuan yang ketujub" 
Hadis tersebut bertentangan dengan ayat $\mathrm{Al}$ Qur'an surah Al A'raf 187 yang berbunyi:

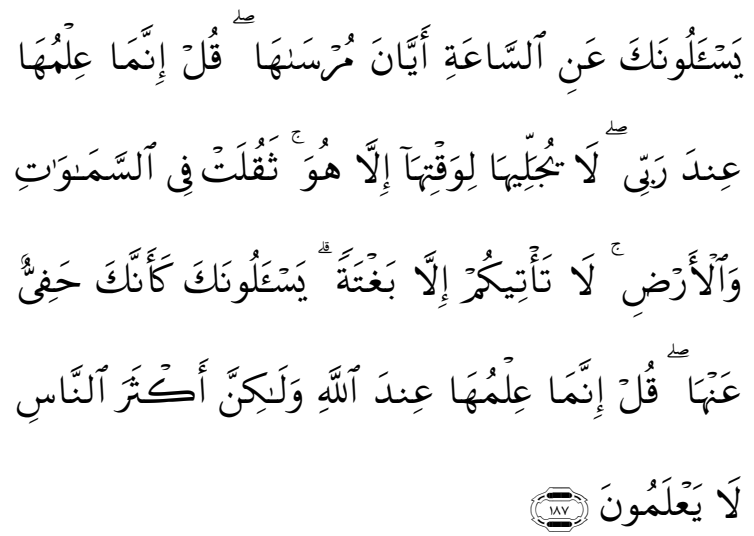

Artinya: mereka menanyakan kepadamu tentang kiamat: "Bilakah terjadinya?" Katakanlab: "Sesunggubnya pengetabuan tentang kiamat itu adalab pada sisi Tubanku; tidak seorangpun yang dapat menjelaskan waktu kedatangannya selain Dia. kiamat itu Amat berat (buru haranya bagi makbluk) yang di langit dan di bumi. kiamat itu tidak akan datang kepadamu melainkan dengan tibatiba". mereka bertanya kepadamu seakanakan kamu benar-benar mengetabuinya. Katakanlah: "Sesunggubnya pengetahuan tentang bari kiamat itu adalah di sisi Allah, tetapi kebanyakan manusia tidak Mengetabui".(QS Al A,raf 187)

3) Berlawanan dengan sunnah / Hadis Mutawatir. Contohnya:

اذا حد ثتم بحديث يوافق الحق فخذوا به حدثت به ام لم احدث

"Artinya: Jika diriwayatkan kepada kamu tentang suatu hadis yang sesuai dengan kebenaran, maka ambillah dia, baik aku ada mengatakannya ataupun tidak"

Perkataan diatas bertentangan dengan hadis yang berbunyi:

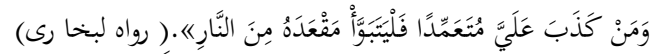
Artinya: "Siapa yang berdusta terbadapku dengan sengaja maka hendaklah dia menempati tempatnya di neraka"

4) Berlawanan dengan ijma yang disepakati para sahabat/ulama. Contohnya:

$$
\text { لا يد خل النار كل من يسمى محمد او اهمد }
$$

Artinya: "Setiap yang bernama Muhammad atau Abmad tidak akan masuk neraka"

Hadis ini adalah maudhu, karena bertentangan dengan sunnah Rasulullah. Karena keselamatan dari nereka tidak tergantung dengan nama saja, tetapi tergantung kepada iman dan amal shaleh serta rahmat Allah SWT.

\section{Hukum Meriwayatkan Hadist Maudlu}

Diharamkan meriwayatkan hadits maudhu dengan menyandarkannya kepada Nabi saw, kecuali hanya memberikan contoh tentang hadis maidlu dengan menjelaskan kepalsuannya.Kerena meriwayatkan hadis maudlu adalah satu bentuk dusta kepa nabi saw. Nabi saw bersabda:

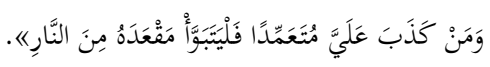

Artinya: "Siapa yang berdusta terbadapku dengan sengaja maka hendaklah dia menempati tempatnya di neraka "(HR. Bukhari)

Keharaman meriwayatkan hadis Maudhu ini, berlaku pada semua keadaan, baik yang berkaitan dengan hal hukum, certera, targhib-tarhib ( dorongan kebaikan -ancaman keburukan) juga yang berkaitan dengan lainnya. Nabi saw bersabda:

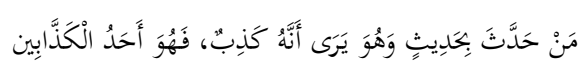

Artinya: "Siapa yang menceriterakan suatu hadis (tentang aku) dan dia tabu bahwa itu dusta, maka dia termasuk golongan pendusta"(HR Ahmad: 18211)

\section{Penanggulangan dan pemberantasan Hadis Maudhu}

Para ulama mengambil langkah yang sangat baik untuk memberantas dan memerangi pemalsu hadi serta berusaha menanggulangi dan menghindarkan bahaya para pemalsu hadis. Untuk itu, mereka menggunakan berbagai cara yang sangat baik diantaranya sebagai berikut: 
a. Meneliti karakteristik para rawi dengan mengamati tingkah laku dan riwayat mereka.

b. Memberi peringatan keras kepada para pendusta dan mengungkap kejelekan mereka, dengan mengumumkan kedustaan mereka kepada para pemuka masyarakat.

c. Pencarian sanad hadis, sehingga mereka tidak menerima hadis yang tidak bersanad, bahkan hadis yang demikian mereka anggap sebagai hadis yang batil.

d. Menguji kebenaran hadis dengan membandingkannya dengan riwayat yang melalui jalur lain dan hadi-hadis yang telah diakui keberadaannya.

e. Menetapkan pedoman-pedoman untuk mengungkapkan hadis maudhu'.

f. Menyusun kitab himpunan hadis-hadis maudhu' untuk memberi penerangan dan peringatan kepada masyarakt tentang keberadaan hadis-hadis tersebut.( Nurudin Itr :317-319)

\section{Akibat Munculnya Hadis Maudhu}

Tersebarnya hadis Maudlu di tengah-tengah masyarakat, meskipun ada hadits maudlu yang isinya baik, namun banyak diantaranya yang membawa dampak negative (akibat) antara lain:

a. Menimbulkan dan mempertajam perpecahan dikalangan ummat Islam.

Suatu mazhab/golongan yang diserang oleh pihak / golongan lain dengan menggunakan hadis palsu, berusaha membela dan mempertahankan kelompoknya, dan bahkan dengan balas menyerang kelompok penyerangnya dengan membuat hadis palsu juga.

Akibatnya terjadilah saling menyerang dan merendahkan. Ini berakibat pada semakin tajamnya perpecahan dikalangan ummat Islam. Tajamnya pertentangan ini tentu akan melemahkan persatuan dan kesatuan ummat Islam dan bahkan dapat mengakibatkan ummat Islam menjadi bercerai berai. Akibat semacam ini sungguh sangat tidak diharapkan, karena ummat Islam disuruh untuk bersatu, sebagaimana dijelaskan dalam Al Qur'an:

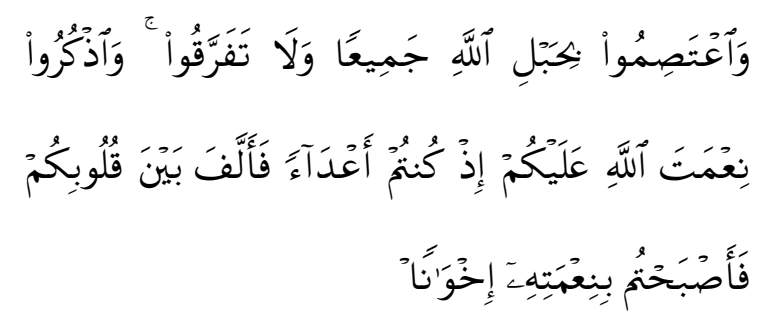

Artinya: "dan berpeganglah kamu semuanya kepada tali (agama) Allah, dan janganlah kamu bercerai berai, dan ingatlah akan nikmat Allah kepadamu ketika kamu dabulu (masa Jahiliyah) bermusub-musuban, Maka Allah mempersatukan hatimu, lalu menjadilah kamu karena nik.mat Allab, (QS. Ali Imran :103)

Perpecahan tentu dapat menyebabkan ummat Islam semakin lemah dan bahkan kehilangan kekuatan, saat-saat seperti itu menjadi peluang bagi mereka yang ingin menyerang dan menghancurkan ummat Islam.

Di dalam ayat lain, Allah melarang ummat Islam untuk berepccah belah dan berbantahbantahan, sebagai berikut:

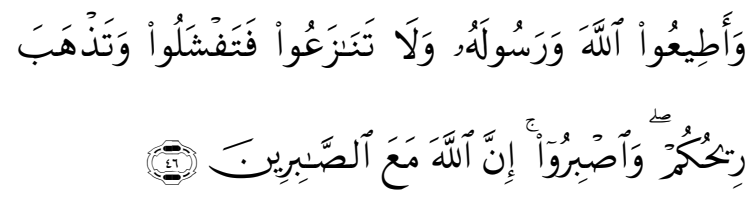

Artinya: "dan taatlah kepada Allah dan Rasul-Nya dan janganlah kamu berbantab-bantahan, yang menyebabkan kamu menjadi gentar dan bilang kekuatanmu dan bersabarlah. Sesungguhnya Allah beserta orang-orang yang sabar.(QS Al Anfal : 46)

b. Mencemarkan pribadi Rasulullah saw

Munculnya hadis-hadis Maudlu yang isinya kadang-kadang bertentangan dengan akal sehat, logika yang benar dan fakta yang ada, dapat mencemarkan pribadi Rasulullah saw. Karena dari hadis-hadis palsu itu tergambar bahwa Rasulullah saw seolah-olah, pelupa, bodoh, egois dan kekanak-kanakan. Hal ini sangat bertentanagn dengan fakta pribadi Rasulullah saw yang sebenarnya. Dari fakta sejarah 
diketahui bahwa Rasulullah saw diakui memiliki kecerdasan, keluhuran budi dan kemuliaannya, pengakuan itu tidak hanya datang dari para sahabat dan orang-orang mukmin saja, tetapi juga para penentang dan musuh-musuh beliau.

Membuat sebuah perkataan, kemudian menyandarkannya kepada Rasulullah saw adalah sebuah kesalahan besar dan sangat berbahaya. Dampaknya dapat menimpa dirinya sendiri dan juga orang lain. Rasulullah saw memberikan ultimatum yang tegas kepada mereka yang berani berdusta terhadap beliau dengan sabdanya:

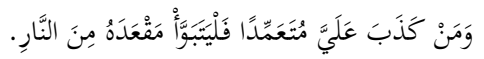

Artinya: "Siapa yang berdusta terhadapku dengan sengaja maka hendaklah dia menempati tempatnya di neraka" (Shahih Bukhari. Juz I h.38)

c. Mengaburkan pemahaman terhadap Islam.

Sebagaimana disebutkan terdahulu bahwa sumber Islam setelah Al Qur'an adalah Hadist Rasulullah saw. Dalam hal ini tentulah bahwa nilai-nilai keislaman yang menjadi pedoman bagi ummat Islam banyak bersumber dari Al Hadits. Kalau hadis yang menjadi sumber itu palsu, berbeda dan bahkan bertentangan dengan Islam yang sebenarnya, akan terjadilah pemahaman yang salah terhadap Islam, sehingga Islam tidak dapat diakui dan dipercaya sebagai agama fitrah yang dapat membimbing dan membawa manusia untuk mencapai kebahagiaan dan kesejahteraan dunia dan akhirat.

Akibat semacam ini dapat kita lihat sekarang, bahwa masyarakat Islam tidak sepenuhnya menjadikan Islam sebagai pedoman hidupnya, hal ini mungkin disebabkan mereka belum yakin sepenuhnya terhadap Islam.

Golongan dari luar Islam yang ingin mempelajari Islam, bila mereka mendapatkan informasi tentang Islam dari sumber yang salah (palsu) mungkin perhatian mereka terhadap Islam akan berkurang, atau mungkin pula mereka meremehkan dan mencemoohkannya karena menganggap Islam tidak logis, tidak masuk akal karena bertentangan dengan data dan fakta yang ada. d. Melemahkan jiwa dan semangat keislaman.

Salah paham terhadap Islam, dapat menimbulkan keraguan dan kebimbangan terhadap Islam menyelimuti ummat Islam yang tentu saja hal ini dapat membawa akibat yang fatal yaitu melemahnya jiwa dan semangat keislaman. Bila jiwa dan semangat keislaman ini lemah, maka dikuatirkan kekuatan yang ada pada ummat Islam akan lumpuh, sehingga ummat Islam tidak lagi menjadi Ummat yang disegani sebagaimana ummat Islam terdahulu yang sanggup mengalahkan lawan meskipun jumlah mereka jauh lebih sedikit disbanding dengan jumlah lawan yang jauh lebih banyak, sebagaimana disebutkan dalam $\mathrm{Al}$ qur'an:

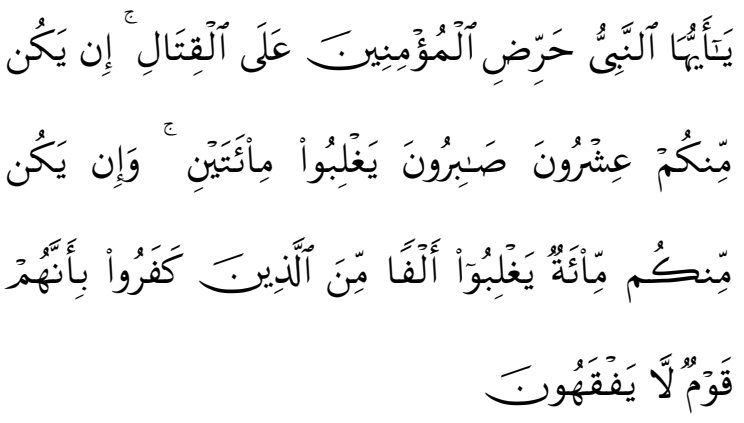

Artinya: "Hai Nabi, Kobarkanlah semangat Para mukmin untuk berperang. jika ada dua puluh orang yang sabar diantaramu, niscaya mereka akan dapat mengalabkan dua ratus orang musuh. dan jika ada seratus orang yang sabar diantaramu, niscaya mereka akan dapat mengalabkan seribu dari pada orang kafir, disebabkan orang-orang kafir itu kaum yang tidak mengerti (QS AL anfal: 65).

Kemenangan yang diperoleh ummat Islam yang minoritas saat itu terhadap orang kafir yang mayoritas, disebabkan karena ummat Islam saat itu mempunyai jiwa semangat Islam yang kuat dan mantap. Tetapi bila jiwa dan semangat Islam sudah lemah, maka meskipun dalam kaadaan mayoritas, tentu kekalahan yang didapat nauzubillahi min zalik.

\section{Penutup}

Berdasar kepada uraian terdahulu, dapatlah disimpulkan sebagai berikut: 
1. Yang dimaksud hadis maudlu (palsu) adalah: Segala riwayat yang dinisbahkan kepada Rasulullah saw dengan jalan mengada-ada atau berbohong tentang apa yang tidak pernah diucapkan dan dikerjakan oleh Rasulullah saw, serta tidak pula disetujui beliau.

2. Faktor yang menyebabkan munculnya hadis maudhu adalah: Kebencian dan permusuhan, politik, fanatisme yang keliru, kebodohan, popularitas dan ekonomi.

3. Ciri-ciri hadis maudhu diantaranya adalah: Perawinya pendusta, pengakuan dari pembuatnya, terdapat kerancuan lafaz dan makna. bertentangan dengan akal sehat, bertentangan dengan $\mathrm{Al}$ qur'an dan Hadits Mutawatir, meyalahi fakta sejarah, menyalahi kaedah umum dan disepakati (ijma) ulama, isinya sejalan dengan fanatisme perawinya, menjanjikan pahala yang sangat besar terhadap perbuatan kecil dan memberikan ancaman besar terhadap kesalahan kecil.

4. Penanggulangan terhadap hadist maudhu dilakukan para ulama dilakukan dengan: Meneliti perawi hadist, pencarian dan penelitian sanad, tindakan tegas terhadap pemalsu hadis dan mengungkap keburukannya, menetapkan ketentuan untuk mengungkap hadis Maudlu, dan menyusun kitab-kitab kumpulan hadis maudlu agar diketahui masyarakat.

5. Akibat dari munculnya hadis maudlu (palsu) diantaranya adalah: Menimbulkan dan mempertajam perpecahan dikalangan ummat Islam, mencemarkan pribadi Nabi saw, mengaburkan pemahaman terhadap Islam. melemahkan jiwa dan semangat keislaman.

\section{Daftar Pustaka}

Abi 'Abdillah Muhammad bin Zaid Al-Qazwini (Ibnu Majah) Sunan Ibnu Majah, Maktabah Al-Ma'arif, Riyadh.

Agus Solahudin. Ulumul Hadist. Bandung: CV. Pustaka Setia.

Ajaj Al-Khathib, As-Sunnah Qabla At-Tadwin, cetakan Maktabah Wahbah, Kairo.1963

Al-Hafizh Ibnu Hajar Al-'Asqalani, Fatbul Bari bi Syarb Shabih Bukhari, cetakan Darul Hadits, Kairo.

Al-Hafizh Ibnu Hajar Al-'Asqalani, Taqribut Tabdził, , cetakan Baitul Afkar Ad-Dauliyyah, Riyadh.

Hasbi Ashshiddiqy, Pokok-pokok Dirayah Ilmu Hadis, Bulan Bintang, Jakarta, 1981.

Hasbi Ashshiddiqy, Sejarah \& Pengantar Ilmu Hadits,Bulan bintang, Jakarta, 1981.

Imam Abi Al-Husain Muslim bin Al-Hajjaj Al-Qusyairi An-Naisaburi Shabih Muslim, cetakan Darul Kutub Al-'Ilmiyyah, Beirut.

Jalaluddin As-Suyuthi, Tadribur Rawi, Daar Thaybah, Riyadh.

Kasman. Hadist Dalam Pandangan Muhammadiyah. Yogyakarta: Penerbit Mitra Pustaka. 2012.

M.M Azami, Studies In Early hadits Literature, alih bahasa: Ali Musthafa Ya'qub, Hadis Nabawi Dan Sejarah Kodifikasinya, pustaka Firdaus Jakarta, 1994.

Mahmud Ath-Thahhan Taisir Musthalabul Hadits, Maktabah Al-Ma’arif, Riyadh.

Muhammad Alawi al Maliki, Almanhalu al Lathif fi ushulil Hadits asyarif, alih bahasa Adnan Qahar, Ilmu Ushul Hadits, Pustaka Pelajar, Yogyakarta 2012.

Muhammad Alfatih Suryadilaga, Metodologi Penelitian Hadis, Yogyakarta, Teras, 2009. 
Muhammad ibn Ali Asysyaukani, Al Fawaid al majmu'ah fi ahaditsil maudluah,dar Kutub al Ilmiyah, Bairut, Libanon

Muhammad Nashiruddin Al-Albani, Silsilah Al-Ahadits Adh-Dha'ifah wal Maudhu'ah cetakan Maktabah AlMa'arif, Riyadh.

Mushthafa As-Siba'i As-Sunnah wa Makanatuba fit Tasyri' Al-Islami, cetakan Al-Maktab Al Islami, Damaskus. Tt

Musthafa Zahri, Kunci memahami Musthalah Hadits,Bina Ilmu Surabaya, 1981.

Nurrudin, Ulumul Hadis.PT Remaja Rosdakarya Bandung. Cetakan pertama. 2012

Subhi al Shaleh, Ulum al Hadits wa Musthalahubu, Darul ilm, Beirut 1997

Syuhudi Ismail, Pengantar Ilmu Hadits, Angkasa, Bandung.Tt 